\title{
GEOCHRONOLOGY OF VEGETATION STAGES OF SOUTH-EAST BALTIC COAST (KALININGRAD REGION) DURING THE MIDDLE AND LATE HOLOCENE
}

\author{
KHIKMATULLA ARSLANOV ${ }^{1}$, OLGA DRUZHININA ${ }^{2}$, LARISA SAVELIEVA ${ }^{1}$, DMITRY SUBETTO ${ }^{3}$, IVAN \\ SKHODNOV $^{4}$, PAVEL DOLUKHANOV $^{5}$, GENNADY KUZMIN ${ }^{6}$, SERGEY CHERNOV $^{1}$, \\ FEDOR MAKSIMOV ${ }^{1}$ and SEGEY KOVALENKOV ${ }^{3}$ \\ ${ }^{1}$ Faculty of Geography and Geoecology, St. Petersburg State University, V.O., 10-Line, 33, 199178, St. Petersburg, Russia \\ ${ }^{2}$ I. Kant State University of Russia,A. Nevsky str., 14 b, 236038, Kaliningrad, Russia \\ ${ }^{3}$ Faculty of Geography of Herzen State Pedagogical University, Moyka, 48, 191186, St. Petersburg, Russia \\ ${ }^{4}$ Scientific Research Center "Prebaltic Archaeology", Emelyanova str., 53 - 6, 236034, Kaliningrad, Russia \\ ${ }^{5}$ School of Historical Studies, Newcastle University, Newcastle upon Tyne, NEI 7RU United Kingdom \\ ${ }^{6}$ All-Russian Research Institute of Peat Industry, Marsovo Pole, 5, 196105, St. Petersburg, Russia
}

Received 12 July $2010 \quad$ Accepted 19 January 2011

\begin{abstract}
The raised bog sediments that have been continuously accumulated over time represent the most suitable natural object which enables us to reconstruct Late Glacial and Holocene vegetation and palaeoclimates. Bog peat consists of organic carbon formed in situ. It contains moss, plant fragments and microfossils that are necessary for the study of palaeovegetation and palaeoclimate. However, a successful study of palaeoenvironment can be carried out on the basis of investigation of a great quantity of samples along the whole peatbog thickness. In the present paper, the authors present the results of palynological, botanical investigations and radiocarbon dating of 31 peat samples taken from the raised bog Velikoye, located in the eastern part of Kaliningrad Region. The data obtained have enabled us to reconstruct the palaeovegetation, reveal the evolution of the bog and determine rate of peat formation at different evolutional stages over the last $7500 \mathrm{cal} \mathrm{BP}$.
\end{abstract}

Keywords: raised bog evolution, palynological analyses, radiocarbon dating, reconstruction of palaeovegetation history.

\section{INTRODUCTION}

At present the issue concerning the role of human and natural impact on climate change is the subject of considerable discussion in connection with observed increase in annual global temperature in recent decades. Peatbog and lake sediments enriched by plant remains, spores and pollen serve as the most suitable natural archives for reconstruction of climate and environmental changes

Corresponding author: K. Arslanov

e-mail: arslanovkh@mail.ru

ISSN 1897-1695 (online), 1733-8387 (print)

(C) 2011 Silesian University of Technology, Gliwice, Poland.

All rights reserved. during Late Pleistocene and Holocene. In the past 15 years we have studied many reference raised bogs sections located in Leningrad and Novgorod regions as well as in the Republic of Karelia. We used the same research method for all sections under study: almost every $10 \mathrm{~cm}$ layer along the whole peatbog length was investigated by palynological, botanical and geochronological $\left({ }^{14} \mathrm{C}\right)$ methods. On the whole, about 500 radiocarbon dates of peat and gyttja samples have been obtained at the Geochronological laboratory of St.-Petersburg State University (Elina et al., 1996; Arslanov et al., 1999, 2001; Dolu- 
khanov et al., 2007). V. Klimanov (1976) developed a statistical method to reconstruct quantitative characteristics of the Late Pleistocene and Holocene climates, based on the statistical relationship between recent spore-pollen spectra and recent climatic conditions. The reconstruction was made on the basis of the palynological and geochronological data obtained from the investigated peatbog and lake deposits (Elina et al., 1996; Arslanov et al., 1999, 2001).

In 2009 complex archaeological and palaeogeographical research aimed at elaborating the history of human early settlement in the Southeast Baltic (the Kaliningrad region, Russian Federation) in Late PleistoceneHolocene was carried out. Palaeobotanical and geochronological investigations of peatbog sediments from raised bog Velikoye located in the eastern part of Kalinigrad region in the valley of the River Sheshupe $\left(54^{\circ} 57^{\prime} 06^{\prime \prime} \mathrm{N}\right.$, $22^{\circ} 20^{\prime} 28^{\prime \prime} \mathrm{E}, 34 \mathrm{~m}$ a.s.l.) were carried out in order to reconstruct vegetation and peatbog evolution stages during the Holocene (Fig. 1).

\section{METHODS}

The area of the raised bog Velikoye is about 2000 hectares. Bog samples were taken using a Giller hand drill. Almost every $10 \mathrm{~cm}$ section of peat sample along the whole peatbog thickness was investigated palynologically and generally geochronologically (using ${ }^{14} \mathrm{C}$ dating method). The botanical composition of each $10-\mathrm{cm}$ layer of samples was also studied. For ${ }^{14} \mathrm{C}$ dating we used liquid scintillation method described by Arslanov et al. (1993). Peat samples for radiocarbon dating were pretreated by heating in $1 \% \mathrm{HCl}$ for $30 \mathrm{~min}$ and then by keeping them in $1 \% \mathrm{NaOH}$ overnight at room temperature. Lithium carbide was synthesized from coal obtained by pyrolysis from the pretreated peat and humic acid samples. To synthesize benzene from acetylene $\mathrm{V}_{2} \mathrm{O}_{5} \cdot \mathrm{Al}_{2} \mathrm{O}_{3} \cdot \mathrm{SiO}_{2}$ catalyst was used, which allowed us to obtain benzene of high purity (with $90-95 \%$ yield). Peat samples for palynological analysis were pretreated by boiling in $10 \% \mathrm{NaOH}$ for $5 \mathrm{~min}$ and then washing with distilled water; the residue was then analysed. Heavy liquid (PD-6 or KK-2.6) was used for pollen extraction from mineral samples (Grichuk, Zaklinskaya, 1948). About 400 terrestrial pollen grains per sample were counted and used as pollen sum for pollen percentage calculations. The percentage of spores was based on the sum of pollen and spores. The TILIA and TILIA GRAPH plotting program was used for graphing the pollen data (Grimm, 1991). Pollen zonation was done by visual inspection.

\section{RESULTS}

31 peat samples were taken from the sediment core and studied by palynological, botanical and geochronological $\left({ }^{14} \mathrm{C}\right)$ methods. ${ }^{14} \mathrm{C}$-dating of the samples were

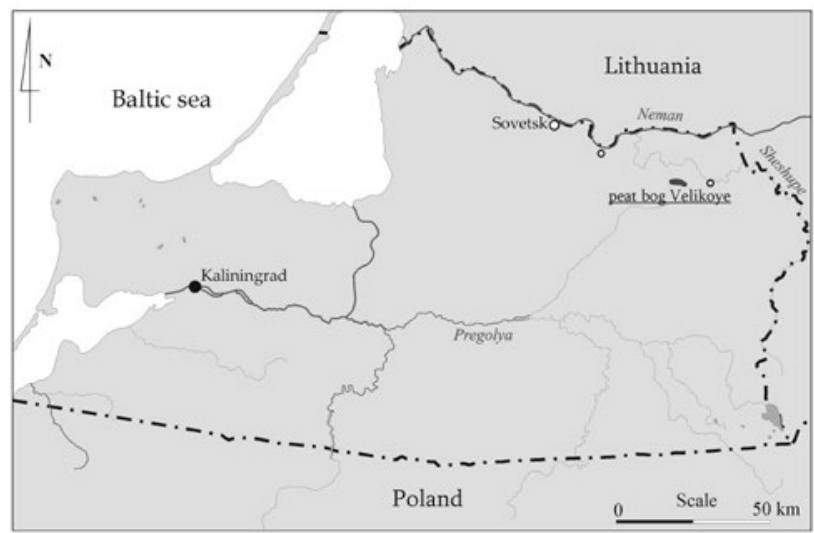

Fig. 1. Location of the peat bog Velikoye (the Kaliningradregion, RF).

performed in geochronological laboratory of St. Petersburg University and the results are presented in Table 1. Dr. G.F. Kuzmin and Dr. L.A. Sozinova carried out the botanical analysis of each $10-\mathrm{cm}$ layer along the core length. As a result the evolution of the given bog in chronological sequence was revealed. A maximum thickness of peat $(660 \mathrm{~cm})$ was revealed in studied peat bog area. The results of the analyses are shown in Table 2. Bog formation began with bogging of black alder forest site where low mire wood peat of high degree of decomposition $(45 \%)$ was deposited. In botanical structure of this peat $30 \mathrm{~cm}$ thick $(660-630 \mathrm{~cm})$, the bark of black alder, birch, pine and willows was identified. This layer was formed within the range from 5630-5480 cal BC to $4780-4625 \mathrm{cal}$ BC. From depth of $630 \mathrm{~cm}$ and less the presence of oligotrophic species of peat Sphagnum fuscum and Sph Magellanicun (up to 5\%) and also Eriophorum vaginatum was identified. From 4780-4625 cal BC to $4530-4370 \mathrm{cal} \mathrm{BC}$ in transitional (mesotrophic) stage a thin layer of wood peat $10 \mathrm{~cm}$ thick $(630-620 \mathrm{~cm})$ was deposited. In this layer the remains of pine, birch and black alder were found. The oligotrophic stage of the bog begins from depth of $620 \mathrm{~cm}$, but small amounts of transitional components and species were found in peat composition up to $500 \mathrm{~cm}$. From the depth of $500 \mathrm{~cm}$ (from 510-460 cal BC to the present time) sphagnum moss peat was deposited with absolute prevalence of Sphagnum fuscum. The presence of wiggles on the plot ${ }^{14} \mathrm{C}$-age vs. calibrated age hampers precise estimation of peat accumulation rate. The layer of peat formed between 410-370 cal BC and 1500-1600 cal AD is the most suitable one for determining the average peat accumulation rate. Here an almost linear graphic relationship between radiocarbon age and calendar age is observed (Stuiver et al, 1998). For the indicated period, peat accumulated at the rate of about $2 \mathrm{~mm} /$ year. The botanical composition of the raised bog Velikoye is typical for the Baltic bog-marsh area (Seaside type of peat accumulation), distinctive feature of which is the formation of a thick layer of homogenous in the botanical composition of Sphagnum peat (Kuzmin, 1993). 
Table 1. Radiocarbon and calendar ages of the peat samples from raised bog Velikoye, Kaliningrad region, bore hole 2. Calibration was made using OxCal programme v. 4.1.7 (Bronk Ramsey et al., 2010) and calibration curve IntCal09 (Reimer et al., 2009).

\begin{tabular}{|c|c|c|c|c|c|}
\hline Lab. code & Type of sample & Depth (m) & ${ }^{14} \mathrm{C}$ age (BP) & $\begin{array}{c}\text { Cal. age ranges } \\
68.2 \% \text { conf. intervals }\end{array}$ & $\begin{array}{c}\text { Cal. age ranges } \\
68.2 \% \text { conf. intervals with using } \\
\text { the age-depth model } \\
\text { (see Fig. } 3 \text { ) }\end{array}$ \\
\hline LU-6261 & Peat and wood remains & $6.6-6.5$ & $6630 \pm 100$ & $5629-5486 \mathrm{BC}(68.2 \%)$ & $5630-5484 \mathrm{BC}(68.2 \%)$ \\
\hline LU-6262 & Peat and wood remains & $6.4-6.3$ & $5830 \pm 70$ & $4782-4606 \mathrm{BC}(68.2 \%)$ & $\begin{array}{c}4833-4813 \mathrm{BC}(6.1 \%) \\
4807-4666 \mathrm{BC}(62.1 \%)\end{array}$ \\
\hline LU-6263 & Peat & $6.2-6.1$ & $5770 \pm 80$ & 4716-4532 BC (68.2\%) & 4552-4454 BC (68.2\%) \\
\hline LU-6265 & Twig & $6.05-5.9$ & $5180 \pm 80$ & $\begin{array}{c}4222-4210 \text { BC }(2.4 \%) \\
4153-4133 \text { BC }(4.2 \%) \\
4057-3936 \text { BC }(47.5 \%) \\
3872-3810 \text { BC }(14.1 \%)\end{array}$ & $\begin{array}{c}4240-4126 \mathrm{BC}(67.6 \%) \\
4112-4110 \mathrm{BC}(0.6 \%)\end{array}$ \\
\hline LU-6341 & Peat & $5.9-5.8$ & $4800 \pm 100$ & $\begin{array}{c}\text { 3693-3682 BC }(2.6 \%) \\
3664-3506 \text { BC }(54.0 \%) \\
3428-3381 \text { BC }(11.6 \%)\end{array}$ & $\begin{array}{c}3756-3726 \text { BC (8.5\%) } \\
3714-3604 \text { BC (59.7\%) }\end{array}$ \\
\hline$\underline{\mathrm{LU}-6342}$ & Peat & $5.7-5.6$ & $4470 \pm 120$ & $3351-3016 \mathrm{BC}$ & $2992-2893 \mathrm{BC}(68.2 \%)$ \\
\hline LU-6267 & Peat & $5.6-5.5$ & $3820 \pm 100$ & $\begin{array}{c}2458-2417 \text { BC }(8.3 \%) \\
2410-2190 \text { BC }(51.5 \%) \\
2180-2142 \text { BC }(8.4 \%)\end{array}$ & $\begin{array}{c}2618-2610 \text { BC }(2.4 \%) \\
2580-2515 \text { BC }(46.7 \%) \\
2492-2441 \text { BC }(19.1 \%)\end{array}$ \\
\hline LU-6272 & Peat & $5.4-5.3$ & $3620 \pm 70$ & $\begin{array}{l}2125-2090 \text { BC }(10.0 \%) \\
2044-1890 \text { BC }(58.2 \%)\end{array}$ & $\begin{array}{l}1926-1879 \text { BC }(24.1 \%) \\
1845-1772 \text { BC }(44.1 \%)\end{array}$ \\
\hline LU-6343 & Peat & $5.3-5.2$ & $3300 \pm 70$ & $1665-1500 \mathrm{BC}(68.2 \%)$ & $\begin{array}{c}1510-1493 \text { BC }(7.7 \%) \\
1486-1414 \text { BC }(60.5 \%)\end{array}$ \\
\hline LU-6273 & Peat & $5.2-5.1$ & $2680 \pm 60$ & $896-801 \mathrm{BC}(68.2 \%)$ & $\begin{array}{l}\text { 888-871 BC (12.9\%) } \\
865-806 \text { BC (55.3\%) }\end{array}$ \\
\hline LU-6274 & Peat & $5.0-4.9$ & $2160 \pm 70$ & $\begin{array}{c}357-284 \mathrm{BC}(25.6 \%) \\
256-247 \mathrm{BC}(2.4 \%) \\
234-111 \mathrm{BC}(40.2 \%)\end{array}$ & $507-458 \mathrm{BC}(68.2 \%)$ \\
\hline LU-6275 & Peat & 4.8-4.7 & $2230 \pm 60$ & $\begin{array}{l}381-348 \mathrm{BC}(15.6 \%) \\
316-208 \mathrm{BC}(52.6 \%)\end{array}$ & $411-371 \mathrm{BC}(68.2 \%)$ \\
\hline LU-6277 & Peat & $4.6-4.5$ & $2110 \pm 80$ & $\begin{array}{c}350-306 \mathrm{BC}(10.4 \%) \\
209-39 \mathrm{BC}(57.3 \%) \\
8-5 \mathrm{BC}(0.5 \%) \\
\end{array}$ & $340-295$ BC (68.2\%) \\
\hline LU-6278 & Peat & 4.4-4.3 & $2290 \pm 70$ & $\begin{array}{l}406-350 \mathrm{BC}(28.8 \%) \\
310-208 \mathrm{BC}(39.4 \%)\end{array}$ & $266-215$ BC (68.2\%) \\
\hline LU-6279 & Peat & $4.2-4.1$ & $2270 \pm 70$ & $\begin{array}{l}399-350 \mathrm{BC}(25.0 \%) \\
307-209 \mathrm{BC}(43.2 \%)\end{array}$ & $190-132 \mathrm{BC}(68.2 \%)$ \\
\hline LU-6280 & Peat & $4.0-3.9$ & $2150 \pm 70$ & $\begin{array}{c}355-288 \mathrm{BC}(22.2 \%) \\
232-92 \mathrm{BC}(46.0 \%) \\
\end{array}$ & $113-54 \mathrm{BC}(68.2 \%)$ \\
\hline LU-6281 & Peat & $3.8-3.7$ & $1950 \pm 70$ & $38 \mathrm{BC}-126 \mathrm{AD}(68.2 \%)$ & $\begin{array}{c}38-8 \text { BC }(36.2 \%) \\
1 \text { BC-30 AD (32.0\%) }\end{array}$ \\
\hline LU-6282 & Peat & $3.6-3.5$ & $2030 \pm 80$ & $\begin{array}{c}160-132 \text { BC }(8.1 \%) \\
117 B C-54 \text { AD (60.1\%) }\end{array}$ & $\begin{array}{c}\text { 42-88 AD (51.0\%) } \\
100-117 \text { AD (17.2\%) }\end{array}$ \\
\hline LU-6283 & Peat & $3.4-3.3$ & $2060 \pm 70$ & $172 \mathrm{BC}-4 \mathrm{AD}(68.2 \%)$ & $\begin{array}{l}\text { 118-132 AD (17.1\%) } \\
\text { 146-180 AD (37.9\%) } \\
\text { 190-203 AD (13.2\%) }\end{array}$ \\
\hline LU-6284 & Peat & $3.1-3.0$ & $1650 \pm 60$ & $\begin{array}{l}\text { 264-276 AD (3.8\%) } \\
332-438 \mathrm{AD}(50.1 \%) \\
488-530 \mathrm{AD}(14.3 \%) \\
\end{array}$ & $\begin{array}{c}258-308 \mathrm{AD}(66.0 \%) \\
320-322 \mathrm{AD}(2.2 \%)\end{array}$ \\
\hline LU-6285 & Peat & $2.9-2.8$ & $1770 \pm 80$ & $\begin{array}{l}137-200 \mathrm{AD}(18.6 \%) \\
205-344 \mathrm{AD}(49.6 \%)\end{array}$ & $350-400$ AD (68.2\%) \\
\hline LU-6286 & Peat & $2.6-2.5$ & $1560 \pm 60$ & $428-554 \mathrm{AD}(68.2 \%)$ & $482-530 \mathrm{AD}(68.2 \%)$ \\
\hline LU-6287 & Peat & $2.3-2.2$ & $1380 \pm 80$ & $\begin{array}{c}578-708 \mathrm{AD}(61.9 \%) \\
747-766 \mathrm{AD}(6.3 \%)\end{array}$ & 615-658 AD (68.2\%) \\
\hline LU-6288 & Peat & $2.0-1.9$ & $1290 \pm 70$ & $\begin{array}{l}\text { 655-780 AD (64.0\%) } \\
792-805 \mathrm{AD}(4.2 \%) \\
\end{array}$ & 746-784 AD (68.2\%) \\
\hline LU-6289 & Peat & $1.7-1.6$ & $1050 \pm 70$ & $892-1036 \mathrm{AD}(68.2 \%)$ & $884-916$ AD $(68.2 \%)$ \\
\hline
\end{tabular}


K. Arslanov et al.

Table 1. Continuation.

\begin{tabular}{|c|c|c|c|c|c|}
\hline Lab. code & Type of sample & Depth (m) & ${ }^{14} \mathrm{C}$ age (BP) & $\begin{array}{c}\text { Cal. age ranges } \\
68.2 \% \text { conf. intervals }\end{array}$ & $\begin{array}{c}\text { Cal. age ranges } \\
68.2 \% \text { conf. intervals with using } \\
\text { the age-depth model } \\
\text { (see Fig. } 3 \text { ) }\end{array}$ \\
\hline LU-6293 & Peat & $1.1-1.0$ & $1000 \pm 50$ & $\begin{array}{c}986-1048 \text { AD }(43.6 \%) \\
1086-1123 \text { AD }(18.8 \%) \\
1138-1150 \text { AD }(5.8 \%) \\
\end{array}$ & $1136-1166$ AD (68.2\%) \\
\hline LU-6294 & Peat & $0.8-0.7$ & $600 \pm 60$ & $\begin{array}{l}1301-1367 \text { AD }(51.3 \%) \\
1382-1404 \text { AD }(16.9 \%)\end{array}$ & $1274-1305$ AD (68.2\%) \\
\hline LU-6295 & Peat & $0.5-0.4$ & $590 \pm 80$ & $\begin{array}{l}1299-1370 \text { AD (47.3\%) } \\
1380-1412 \text { AD (20.9\%) }\end{array}$ & $1402-1438$ AD (68.2\%) \\
\hline LU-6337 & Peat & $\begin{array}{c}0.30-0.25 \text { (from } \\
\text { pit) }\end{array}$ & $290 \pm 60$ & $\begin{array}{l}1496-1601 \mathrm{AD}(46.6 \%) \\
1616-1661 \mathrm{AD}(21.6 \%)\end{array}$ & 1468-1539 AD (68.2\%) \\
\hline LU-6296 & Peat & $0.2-0.15$ & $300 \pm 70$ & $\begin{array}{l}1490-1603 \text { AD }(49.2 \%) \\
1610-1654 \text { AD }(19.0 \%)\end{array}$ & $1501-1598$ AD (68.2\%) \\
\hline LU-6338 & Peat & $\begin{array}{l}0.15-0.10 \text { (from } \\
\text { pit) }\end{array}$ & $\begin{array}{c}\delta^{14} \mathrm{C}= \\
4.24 \pm 0.99 \%\end{array}$ & $1956 A D$ & \\
\hline
\end{tabular}

Table 2. Botanical composition of peat samples from raised bog Velikoye, evolution of the bog and rate of peat accumulation.

\begin{tabular}{|c|c|c|c|c|}
\hline $\begin{array}{l}\text { Type of peat } \\
\text { bog }\end{array}$ & $\begin{array}{l}\text { Depth } \\
\text { (cm) }\end{array}$ & Species of bog plants (\%) & $\begin{array}{c}\text { Cal age (BC/AD) with using the } \\
\text { age-depth model }\end{array}$ & $\begin{array}{l}\text { Rate of accumula- } \\
\text { tion, (mm/year) }\end{array}$ \\
\hline \multirow[t]{8}{*}{$\begin{array}{l}\text { Oligotrophic } \\
\text { moss peat }\end{array}$} & $5-30$ & $\begin{array}{l}\text { Sphagnum fuscum - 65-85 } \\
\text { Sphagnum angustifolium - 5-20 } \\
\text { Sphagnum magellanicum }-5-10 \\
\text { Eriophorum vag. }-5 \\
\text { Ericaceae }-5-10\end{array}$ & Recent - 1470-1540 AD & \multirow[t]{8}{*}{2.03} \\
\hline & $30-50$ & $\begin{array}{l}\text { Sphagnum fuscum - 35-65 } \\
\text { Sphagnum angustifolium - 20-25 } \\
\text { Sphagnum magellanicum - 10-15 } \\
\text { Eriophorum vag. }-20 \\
\text { Ericaceae }-5\end{array}$ & 1470-1540 AD - 1400-1440 AD & \\
\hline & $50-80$ & $\begin{array}{l}\text { Sphagnum fuscum - 50-90 } \\
\text { Sphagnum angustifolium - 5-20 } \\
\text { Eriophorum vag. }-25 \\
\text { Ericaceae }-5\end{array}$ & 1400-1440 AD - 1270-1310 AD & \\
\hline & $80-90$ & $\begin{array}{l}\text { Sphagnum fuscum - } 35 \\
\text { Sphagnum angustifolium - } 10 \\
\text { Sphagnum magellanicum - } 10 \\
\text { Eriophorum vag. }-40 \\
\text { Ericaceae }-5\end{array}$ & & \\
\hline & $90-100$ & $\begin{array}{l}\text { Sphagnum fuscum - } 90 \\
\text { Ericaceae - } 10\end{array}$ & & \\
\hline & $100-110$ & $\begin{array}{l}\text { Sphagnum fuscum - } 35 \\
\text { Sphagnum angustifolium - } 10 \\
\text { Sphagnum magellanicum - } 5 \\
\text { Eriophorum vag. }-45 \\
\text { Ericaceae }-5\end{array}$ & $1140-1170 \mathrm{AD}$ & \\
\hline & $110-130$ & $\begin{array}{l}\text { Sphagnum fuscum }-85-90 \\
\text { Sphagnum angustifolium - } 5 \\
\text { Eriophorum vag. }-5 \\
\text { Ericaceae }-5\end{array}$ & & \\
\hline & $130-340$ & $\begin{array}{l}\text { Sphagnum fuscum }-85-95 \\
\text { Sphagnum angustifolium }-5 \\
\text { Ericaceae }-5\end{array}$ & 880-920 AD - 120-200 AD & \\
\hline
\end{tabular}


Table 2. Continuation.

\begin{tabular}{|c|c|c|c|c|}
\hline $\begin{array}{l}\text { Type of peat } \\
\text { bog }\end{array}$ & $\begin{array}{l}\text { Depth } \\
\text { (cm) }\end{array}$ & Species of bog plants (\%) & $\begin{array}{c}\text { Cal age (BC/AD) with using the } \\
\text { age-depth model }\end{array}$ & $\begin{array}{l}\text { Rate of accumula- } \\
\text { tion, (mm/year) }\end{array}$ \\
\hline \multirow[t]{6}{*}{$\begin{array}{l}\text { Oligotrophic } \\
\text { moss peat }\end{array}$} & $340-350$ & $\begin{array}{l}\text { Sphagnum fuscum - } 10 \\
\text { Sphagnum angustifolium - } 30 \\
\text { Sphagnum majus }-30 \\
\text { Sphagnum cuspidatum - } 20 \\
\text { Sheuchzeria pal. }-5 \\
\text { Sphagnum magellanicum - } 5 \\
\text { Ericaceae - } 5\end{array}$ & $120-200 \mathrm{AD}$ & \multirow[t]{6}{*}{2.03} \\
\hline & $350-380$ & $\begin{array}{l}\text { Sphagnum fuscum - 70-80 } \\
\text { Sphagnum angustifolium - 15-20 } \\
\text { Sphagnum magellanicum - 5-10 } \\
\text { Ericaceae - } 5\end{array}$ & $40 \mathrm{BC}-30 \mathrm{AD}$ & \\
\hline & $380-390$ & $\begin{array}{l}\text { Sphagnum fuscum - } 10 \\
\text { Sphagnum angustifolium - } 45 \\
\text { Sphagnum majus - } 20 \\
\text { Sphagnum cuspidatum - } 5 \\
\text { Sheuchzeria pal. - } 15 \\
\text { Ericaceae }-5\end{array}$ & & \\
\hline & $390-400$ & $\begin{array}{l}\text { Sphagnum fuscum - } 25 \\
\text { Sphagnum angustifolium - } 25 \\
\text { Eriophorum vag. }-40 \\
\text { Sheuchzeria pal. }-5 \\
\text { Ericaceae }-5\end{array}$ & $110-50 \mathrm{BC}$ & \\
\hline & $400-490$ & $\begin{array}{l}\text { Sphagnum fuscum - 80-95 } \\
\text { Sphagnum angustifolium - } 5 \\
\text { Sphagnum magellanicum - } 5 \\
\text { Eriophorum vag. }-5 \\
\text { Ericaceae }-5-10\end{array}$ & $\begin{array}{c}110-50 \mathrm{BC} \\
- \\
410-370 \mathrm{BC}\end{array}$ & \\
\hline & $490-500$ & $\begin{array}{l}\text { Sphagnum fuscum - } 45 \\
\text { Sphagnum magellanicum - } 30 \\
\text { Sphagnum angustifolium - } 5 \\
\text { Sheuchzeria pal. - } 5 \\
\text { Eriophorum vag. - } 5 \\
\text { Ericaceae - } 10\end{array}$ & $510-460 \mathrm{BC}$ & \\
\hline & $500-540$ & $\begin{array}{l}\text { Sphagnum fuscum - 20-40 } \\
\text { Sphagnum magellanicum - } 15-30 \\
\text { Sphagnum angustifolium - 5-10 } \\
\text { Sheuchzeria pal. - 5-10 } \\
\text { Eriophorum vag. }-25-35 \\
\text { Ericaceae - } 5\end{array}$ & $\begin{array}{c}510-460 \mathrm{BC} \\
- \\
1930-1770 \mathrm{BC}\end{array}$ & \multirow[t]{4}{*}{0.27} \\
\hline & $540-560$ & $\begin{array}{l}\text { Sphagnum fuscum - 10-15 } \\
\text { Sphagnum magellanicum - 20-25 } \\
\text { Sphagnum angustifolium - } 5 \\
\text { Sheuchzeria pal. - } 5 \\
\text { Eriophorum vag. }-45-55 \\
\text { Ericaceae }-5\end{array}$ & $\begin{array}{c}1930-1770 \text { BC } \\
- \\
2620-2440 B C\end{array}$ & \\
\hline & $560-600$ & $\begin{array}{l}\text { Sphagnum fuscum }-5-10 \\
\text { Sphagnum magellanicum - 5-10 } \\
\text { Sphagnum angustifolium - } 5 \\
\text { Sheuchzeria pal. }-5 \\
\text { Eriophorum vag. }-65-75 \\
\text { Ericaceae }-5 \\
\text { Pinus }-5-10\end{array}$ & $\begin{array}{c}2620-2440 \text { BC } \\
- \\
4240-4110 B C\end{array}$ & \\
\hline & $600-620$ & $\begin{array}{l}\text { Sphagnum fuscum - } 5 \\
\text { Sphagnum magellanicum - } 5 \\
\text { Sphagnum angustifolium - } 5 \\
\text { Sheuchzeria pal. }-5 \\
\text { Eriophorum vag. }-50-80 \\
\text { Ericaceae }-5 \\
\text { Pinus, Betula - } 10-30\end{array}$ & $\begin{array}{c}4240-4110 \mathrm{BC} \\
- \\
4550-4450 \mathrm{BC}\end{array}$ & \\
\hline
\end{tabular}


Table 2. Continuation.

\begin{tabular}{|c|c|c|c|c|}
\hline $\begin{array}{l}\text { Type of peat } \\
\text { bog }\end{array}$ & $\begin{array}{l}\text { Depth } \\
\text { (cm) }\end{array}$ & Species of bog plants (\%) & $\begin{array}{c}\text { Cal age (BC/AD) with using the } \\
\text { age-depth model }\end{array}$ & $\begin{array}{l}\text { Rate of accumula- } \\
\text { tion, (mm/year) }\end{array}$ \\
\hline $\begin{array}{l}\text { Mesotrophic } \\
\text { wood peat }\end{array}$ & $620-630$ & $\begin{array}{l}\text { Sphagnum fuscum - } 5 \\
\text { Sphagnum magellanicum - } 5 \\
\text { Sphagnum angustifolium - } 5 \\
\text { Eriophorum vag. }-20 \\
\text { Ericaceae }-5 \\
\text { Pinus, Betula, Alnus gl. }-65\end{array}$ & $4550-4670 \mathrm{BC}$ & \multirow[t]{4}{*}{0.37} \\
\hline \multirow[t]{3}{*}{$\begin{array}{l}\text { Low mire wood } \\
\text { peat }\end{array}$} & $630-640$ & $\begin{array}{l}\text { Betula humilis, Alnus glutinosa, } \\
\text { Betula pubescens - } 95 \\
\text { Sheuchzeria pal. }-5\end{array}$ & $4830-4630 \mathrm{BC}$ & \\
\hline & $640-650$ & Betula, Alnus - 100 & & \\
\hline & $650-660$ & Alnus Betula, Salix - 100 & $5630-5480 \mathrm{BC}$ & \\
\hline
\end{tabular}

The bog sediments of $657 \mathrm{~cm}$ in thickness were studied with the method of the spore-pollen analysis. All samples contained amounts of microfossils sufficient for statistical analysis. In each preparation about 400 grains were counted with the exception of samples of flooded peat. Analysing the characteristic changes in the composition of flora and quantitative ratios of pollen of various plants, in the spore-pollen diagram five pollen zones can be distinguished, the formation of which occurred during the Boreal-Subatlantic time under the Blytt-Sernander scheme (Fig. 2).

LPAZ-1: Pinus-Cyperaceae-Polypodiaceae, $660-650 \mathrm{~cm}$. Zone 1 is characterized by domination of Pinus (40\%) and Betula pollen (25\%). The Alnus pollen content reach $10 \%$ and Corylus - 5\%. Percentages of herb pollen including Cyperaceae (15\%), Artemisia (7\%), Rosaceae $(3 \%)$ and Poaceae $(2 \%)$ are relatively high $(27 \%)$. The Polypodiaceae dominate (25\%) among spores. The green algae of Pediastrum are notable only in this zone (37\%).

LPAZ-2: Alnus, $650-600 \mathrm{~cm}$. The composition of spore-pollen spectra changes very sharply. The main dominant becomes Alnus pollen (50-60\%), the pollen of Quercus, Ulmus, Tilia, Fraxinus also appear. The pollen of herb and spore plants is represented by some grains only.

LPAZ-3: Alnus-Quercus-Corylus-Sphagnum, $600-515 \mathrm{~cm}$. Zone 3 is distinguished from zone 2 by the highest percentage of Quercus pollen (18\%), Tilia (6\%), Ulmus (4\%); also appear Ericaceae pollen at the beginning of this zone and Picea pollen - at the end of the zone. Sphagnum also attains maximum percentages (62\%).

LPAZ-4: Alnus-Picea-Carpinus, $515-60 \mathrm{~cm}$. The main particularity of fourth zone is the appearance of Carpinus pollen (13\%) and a significant increase of both Picea and Betula pollen up to $15 \%$ and $35 \%$ correspondingly and a decrease of Pinus (10\%), Alnus (15\%), Quercus $(3 \%)$.

LPAZ-5: Pinus-Poaceae-Calluna, 60-0 cm. Pinus pollen dominates in spore-pollen spectra of this zone (30\%), Betula (25\%) and Alnus (10\%) pollen follow.
Pollen of herbs content is increased up to $33 \%$ including Poaceae (8\%) and Calluna (14\%).

Results of the spore-pollen analysis allow us to conclude that during the formation of pollen zones 2 and 3 in the second half of Atlantic period and practically all Subboreal period the spectra contain maximum quantity of alder $(40-60 \%)$ and broadleaf species of trees such as elm, linden, oak (in total up to $20 \%$ ) and hazel grove (up to $20 \%$ ).

Data of spore-pollen analysis of a bog Velikoye sediments allow to reveal the dynamics of tree species.

Throughout the whole section absolute domination of pollen of tree species and bushes (80-95\%) was observed. Only at the end of the Subatlantic period a reduction of pollen of wood species to $65 \%$ and an increase in grassy plants was registered.

Spruce (Picea). Occurrence of the pollen of a fir-tree was registered around $4470{ }^{14} \mathrm{C}$ BP. Further upwards on a section there is a gradual increase in the curve of the spruce pollen content and about $2150{ }^{14} \mathrm{C}$ BP it forms a maximum of $15 \%$. The following considerable peak (approx. $16 \%$ ) is registered at the approx. time $600 \mathrm{BP}$.

Pine (Pinus). The content of pine varies in the section from $5 \%$ to $40 \%$. Its maximum quantity registered at the time of $6630{ }^{14} \mathrm{C}$ BP and last 300 years and less.

Birch arboreal (Betula sect. Albae). The lowest percentage of birch pollen (10-25\%) is registered at the lower part of the section within the time range from 6630 to $2680 \mathrm{BP}$, which is comparable with the Atlantic and Subboreal periods of Holocene. The maximum of $35 \%$ is comparable with the Subatlantic period and corresponds to ca. $1700 \mathrm{BP}$.

Hazel (Corylus). There is a higher content of this pollen (10-20\%) within the time range from $5770{ }^{14} \mathrm{C} \mathrm{BP}$ to 3300 ${ }^{14} \mathrm{C}$ BP, with a maximum of $20 \%$ approx. $4500{ }^{14} \mathrm{C} \mathrm{BP}$. Further up the section its content does not exceed 5\%.

Alder (Alnus). The maximum concentration of alder pollen (30-58\%), as well as hazel, is observed in the lower part of the section within the time range from $6630{ }^{14} \mathrm{C}$ to $3300{ }^{14} \mathrm{C}$ BP with a peak at $5830{ }^{14} \mathrm{C} \mathrm{BP}$. Further there 


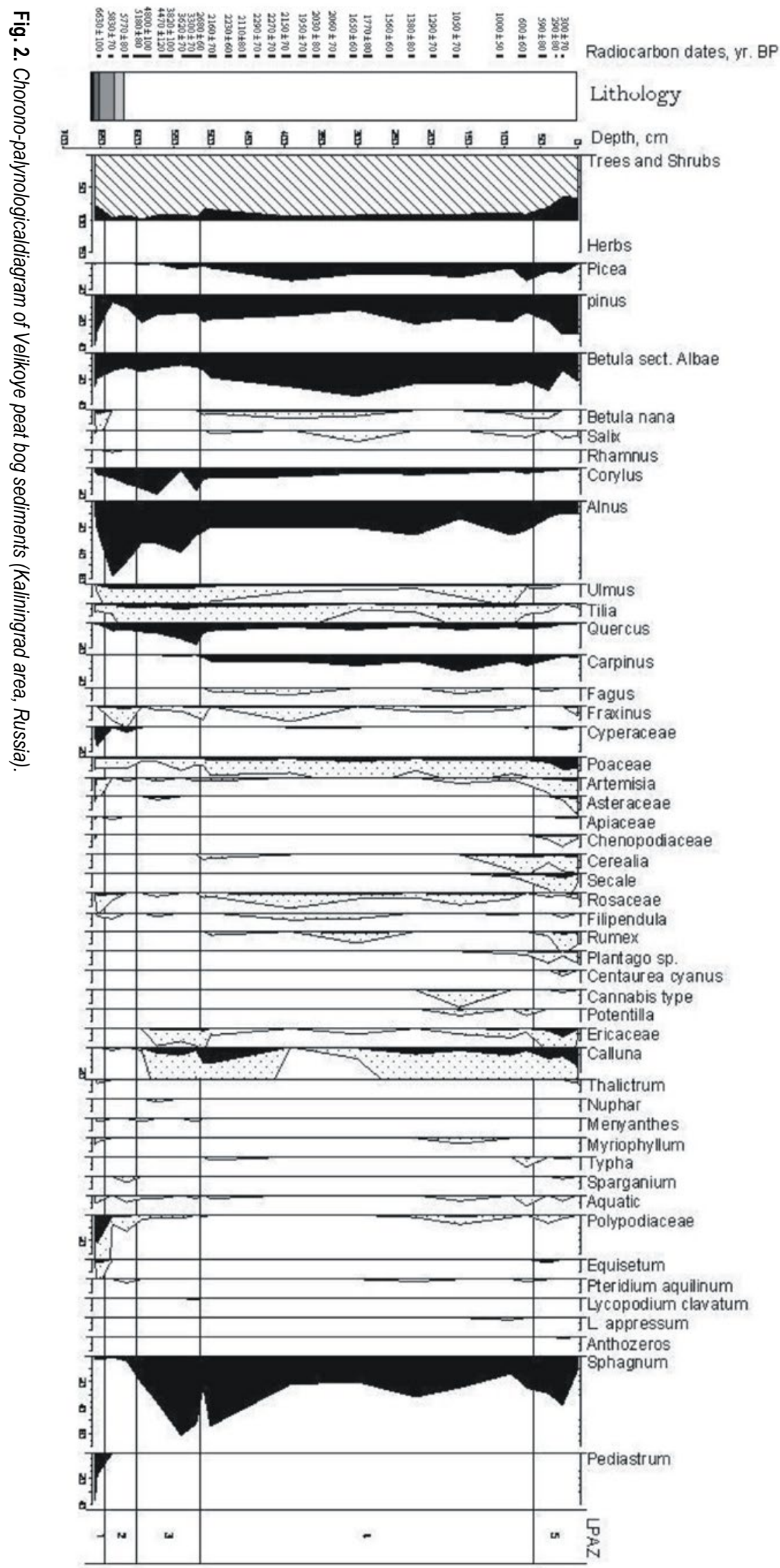




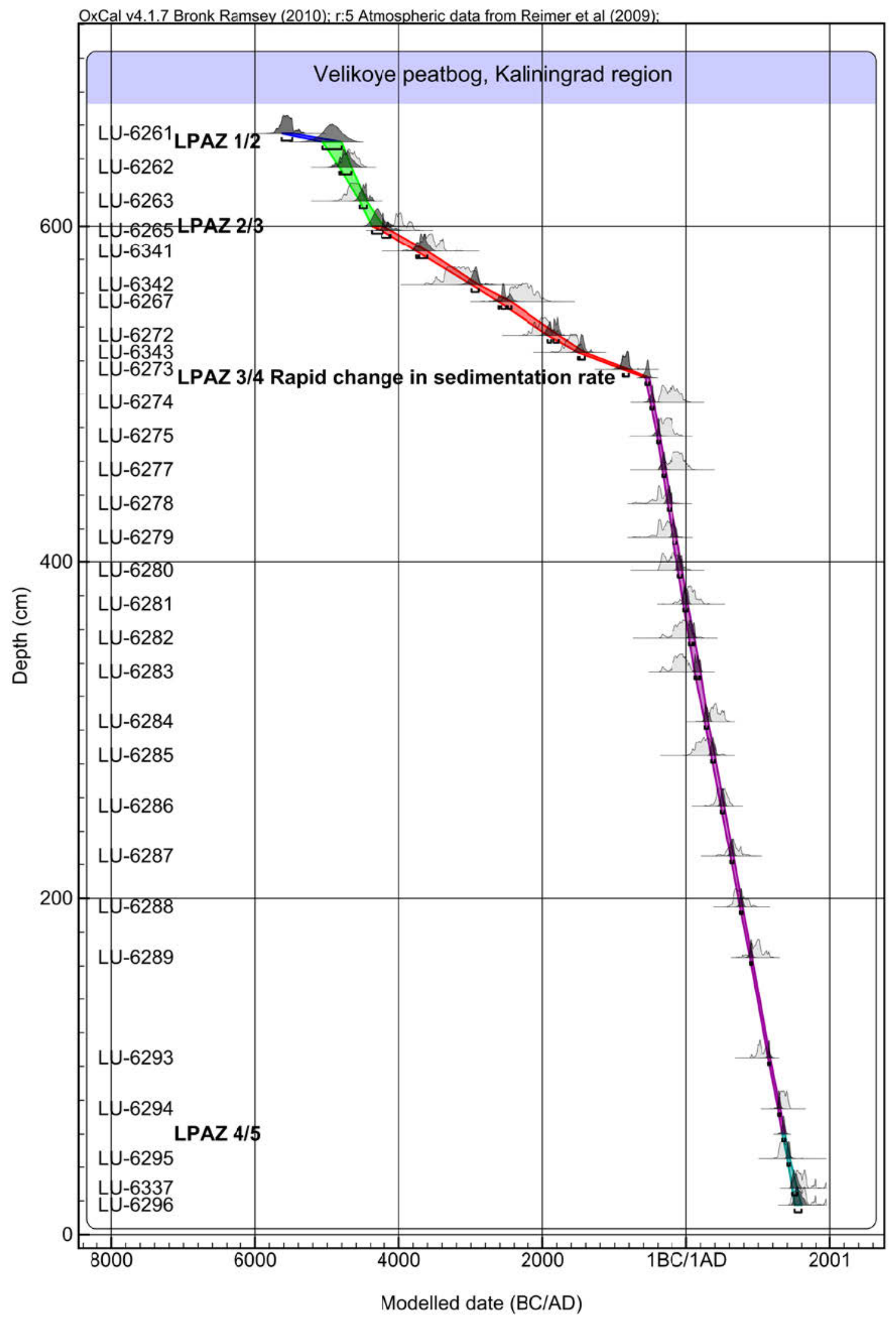

Fig. 3. Age-depth model for peat samples from peat bog Velikoye, Kaliningrad region (Bronk Ramsey et al., 2010). The boundaries between local palynozones (LPAZ, Fig. 2) are also marked. 
is a drop in the pollen curve to $10 \%$ at the end of the Subatlantic period.

Elm (Ulmus) and Linden (Tilia). There is a low concentration of pollen of elm and linden trees, which does not exceed $4-5 \%$ throughout the section. Relatively high pollen content of these broad-leaved trees is associated with $5830-3300{ }^{14} \mathrm{C} \mathrm{BP}$, then it is reduced to $1 \%$ and ca. $600{ }^{14} \mathrm{C}$ BP this pollen disappears from the spore-pollen spectra.

Oak (Quercus). The curve of the content of oak pollen develops similarly to the curves of the pollen content of linden and elm described above, but its presence is slightly higher and amounts to $7-15 \%$ with a maximum of approx. $2680 \mathrm{BP}$. The oak pollen from the spore-pollen spectra became extinct around ca. $300 \mathrm{BP}$.

Hornbeam (Carpinus). The diagram clearly shows the appearance of hornbeam pollen ca. 2160 BP. Then the curve shows an increase in its percentage until $1050 \mathrm{BP}$ where the maximum of $10 \%$ is registered, later there is a lowering of the curve, and in the last 300 years the number of hornbeam pollen has not exceeded $1 \%$.

\section{DISCUSSION}

As seen from Fig. 2 and Tables 1-2, the accumulation of low mire wood peat in the given point began in the second half of the Atlantic period (AT-2) $6630 \pm 100$ BP (5630-5480 cal BC). According to M. Kabaylene (1977), in the adjacent south-western part of Lithuania in the first half of the Atlantic period (AT-1) in the interval from $7750 \pm 260 \mathrm{BP}$ to $6750 \pm 140 \mathrm{BP}$ alder forests with a small admixture of broad-leaved trees (elm, linden, oak ) dominated, whereas in the second half of the Atlantic, during the period from $6750 \pm 140 \mathrm{BP}$ to $5350 \pm 140 \mathrm{BP}$, in southwestern Lithuania alder forests with a substantial admixture of broad-leaved trees (optimal phase for broadleaved trees) dominated.

In Poland, linden and oak forests became an essential component of wood only 8000-7000 BP, while hazel was widespread around 9500 BP (Ralska-Jasiewiczowa and Starkel, 1994). P.M. Dolukhanov (1977) notes that the maximum amount of the pollen of thermophilic plants (alder, elm, linden, oak) in lake and bog sediments of the eastern Baltic region also occurred in the second half of the Atlantic period, the upper limit of which, according to his data, corresponds to $4500 \mathrm{BP}$. The palynological and geochronological data on the composition of forests during the AT-2 are quite consistent with the data of the above authors. However, there are some differences: in the raised bog Velikoye the maximum content of oak pollen is observed in the Subboreal period, just like in Lithuania, but in its later phase - 3300 \pm 70 BP (1510-1410 cal $\mathrm{BC}$ ), whereas in the south-west Lithuania, the maximum content of oak pollen was found in its first half (Kabaylene, 1977). According to the author, culmination distribution of oak in different parts of Lithuania took place at different times. It is worth noting that the fact that Late-Subboreal maximum amount of pollen spruce $(5 \%)$, registered at $3620 \pm 70 \mathrm{BP}(1930-1770 \mathrm{BC})$, is small. This difference may be explained by local conditions and more sections of lake-marsh sediments in this region should be studied.

A distinctive feature of the spore-pollen diagram (Fig. 2) is the fact that the empirical boundary of hornbeam pollen begins only at the end of the Subboreal time $2680 \pm 60$ BP (890-810 cal BC). Three subsequent peaks of pollen hornbeam (about 7\%, 5\% and 7\%) correspond to ${ }^{14} \mathrm{C}$ ages $1770 \pm 80 \mathrm{BP}(350-400 \mathrm{cal} \mathrm{AD}), 1000 \pm 50 \mathrm{BP}$ (1140-1170 AD) and 600 $\pm 60 \mathrm{BP}(1270-1300 \mathrm{AD})$, respectively. Kabaylene (1977) also notes that in the southwestern and south-eastern Lithuania the content of hornbeam in the Atlantic and Subboreal periods was negligible (less than $1 \%$ ), which conforms well with the sporepollen data of sediments from the bog Velikoye.

\section{CONCLUSIONS}

1) Raised bog Velikoye in the valley of the River Scheschupe was formed during Atlantic-Subatlantic periods from $6630 \pm 100 \mathrm{BP}(5630-5480 \mathrm{BC})$ to present time.

2) The evolution of the peat bog included low mire wood peat $(30 \mathrm{~cm})$, mesotrophic wood peat $(10 \mathrm{~cm})$ and oligotrophic moss peat $(620 \mathrm{~cm})$; maximal rate of peat accumulation $(2.03 \mathrm{~mm} /$ year at depth $0-500$ $\mathrm{cm}$ ) occurred over the entire Subatlantic period.

3) Botanical composition of raised bog Velikoye is typical of the Baltic bog-march area (Seaside type of peat accumulation, Kuzmin, 1993) distinctive feature of which is the formation of a thick layer of homogeneous in the botanical composition of Sphagnum peat.

4) According to geochronological $\left({ }^{14} \mathrm{C}\right)$ and palynological studies, the formation of the peat bog from 5630$5480 \mathrm{cal} \mathrm{BC}$ to $1510-1410 \mathrm{cal}$ BC occurred in the optimum climatic conditions: palynozones included maximum quantity of alder pollen $(60 \%)$ and broadlived trees pollen (oak, elm, linden and hazel, in total up to $20 \%$ ).

5) The subsequent time interval from 1510-1410 cal BC 1400-1440 cal AD alder and birch forests dominated in the area under investigation with a considerable admixture of spruce and hornbeam.

\section{ACKNOWLEDGEMENTS}

The investigation is supported by the Russian Foundation for Basic Research (The project 09-06-00150).

Authors are very grateful to Dr. Danuta Michczynska for inestimable assistance in the calibration of radiocarbon dates and constructing the age-depth model according to a new calibration program and models. The authors also thank Makarov A.L. and Starikova A.A. for chemical treatment samples for dating. 


\section{REFERENCES}

Arslanov KhA, Tertychnaya TV and Chernov SB, 1993. Problems and methods of dating low-activity samples by liquid scintillation couting. Radiocarbon 35(3): 393-398.

Arslanov KhA, Savelieva LA, Gey NA, Klimanov VA, Chernov SB, Chernova GM, Kuzmin GF, Tertychnaya TV, Subetto DA and Denisenkov VP, 1999. Chronology of vegetation and palaeoclimatic stages of Northwestern Russia during the Late Glacial and Holocene. Radiocarbon 41(1): 25-45.

Arslanov KhA, Savelieva LA, Klimanov VA, Chernov SB, Maksimov FE, Tertychnaya TV and Subetto DA, 2001. New data on chronology of landscape-palaeoclimatic stages in Northwestern Russia during the Late Glacial and Holocene. Radiocarbon 43(2): 545558.

Bronk Ramsey C, Dee M, Lee S, Nakagawa T, Staff RA, 2010. Developments in the calibration and modeling of radiocarbon dates. $R a$ diocarbon 52(3): 953-961.

Dolukhanov PM, 1977. The Holocene history of the Baltic Sea and ecology of prehistoric settlement. Baltica 6: 227-244.

Dolukhanov PM, Shukurov AM, Arslanov KhA, Subetto DA, Zaitseva GI, Djinoridze EN, Kuznetsov DD, Ludikova TV and Savelieva LA, 2007. Evolution of Waterways and Early Human Settlements in the Eastern Baltic Area. Radiocarbon 49(2): 527-542.
Grichuk VP and Zaklinskaya ED, 1948. Analysis of fossil pollen and spores and its application in palaeogeography. Moscow: $223 \mathrm{pp}$. (in Russian).

Grimm E, 1991. TILIA and TILIAGRAPH. Illinois State Museum, Springfield.

Elina GA, Araslanov KhA and Klimanov VA, 1996. Development stages of Holocene vegetation in Southern and Eastern Karelia. Botanical Journal 81(3): 1-17 (in Russian).

Kabailene M, 1977. About reconstruction of the forests history Lithuania durin the Holocene on evidence derived from palynlogical analysis. Baltica (6): 216-224.

Klimanov VA, 1976. On the procedure of reconstruction of quantitative climatic characteristics of the past. Vestnik of Moscow State University. Geographical Series 2: 92-98.

Kuzmin GF, 1993. Peatbogs and their application. Publication of All Russian Research Institute of Peat Industry, 200 pp (in Russian).

Ralska-Jasiewiczowa M and Starkel L, 1994. Changes of vegetation in Poland during Holocene. [In:] Velichko AA, Starkel L, eds., Palaeogeographical bases of recent landscapes. Moscow, Nauka: 205 pp (in Russian).

Reimer P.J. et al., 2009. IntCal09 and Marine09 radiocarbon age calibration curves, 0-50,000 yrs cal BP. Radiocarbon 51(4): 11111150 .

Stuiver M, Reimer PJ, Bard E et al., 1998. INTCAL 98 Radiocarbon calibration, 24,000-0 cal BP. Radiocarbon 40(3): 1041-1083. 